\title{
Reformation jubilees: Is there cause for celebration in 2017? - What remains?
}

\begin{tabular}{|c|c|}
\hline $\begin{array}{l}\text { Author: } \\
\text { Werner Klän }\end{array}$ & \\
\hline $\begin{array}{l}\text { Affiliations: } \\
{ }^{1} \text { Lutherische T } \\
\text { Hochschule O } \\
\text { Systematische } \\
\text { Germany }\end{array}$ & $\begin{array}{l}\text { heologische } \\
\text { berursel, } \\
\text { Theologie, }\end{array}$ \\
\hline $\begin{array}{l}{ }^{2} \text { Department } \\
\text { History and Pc } \\
\text { of Theology, } U \\
\text { Pretoria, Sout }\end{array}$ & $\begin{array}{l}\text { f Church } \\
\text { lity, Faculty } \\
\text { Iniversity of } \\
\text { h Africa }\end{array}$ \\
\hline $\begin{array}{l}\text { Note: } \\
\text { This article, or } \\
\text { in German an } \\
\text { 'Reformations } \\
\text { ist } 2017 \text { zufeie } \\
\text { is bleibt?', is tr } \\
\text { Klaudia Ringel }\end{array}$ & $\begin{array}{l}\text { iginally written } \\
\text { d entitled } \\
\text { jubiläen: Was } \\
\text { rn? - Was } \\
\text { ranslated by } \\
\text { mann }\end{array}$ \\
\hline $\begin{array}{l}\text { Corresponder } \\
\text { Werner Klän }\end{array}$ & ce to: \\
\hline $\begin{array}{l}\text { Email: } \\
\text { werner.klaen }\end{array}$ & Dgmx.de \\
\hline $\begin{array}{l}\text { Postal addres } \\
\text { Altkönigstraß } \\
\text { Oberursel, Ge }\end{array}$ & $\begin{array}{l}150,61440 \\
\text { rmany }\end{array}$ \\
\hline $\begin{array}{l}\text { Dates: } \\
\text { Received: } 10 \mathrm{~J} \\
\text { Accepted: } 18 \\
\text { Published: } 27\end{array}$ & $\begin{array}{l}\text { uly } 2015 \\
\text { July } 2015 \\
\text { Oct. } 2015\end{array}$ \\
\hline $\begin{array}{l}\text { How to cite th } \\
\text { Klän, W.R.A., } \\
\text { 'Reformation } \\
\text { there cause fo } \\
\text { in } 2017 \text { ? - Wh } \\
\text { HTS Teologies } \\
\text { Theological St } \\
\text { Art. \#3111, } 14 \\
\text { dx.doi.org/10 } \\
\text { v71i3.3111 }\end{array}$ & $\begin{array}{l}\text { is article: } \\
2015, \\
\text { ubilees: Is } \\
\text { r celebration } \\
\text { lat remains?', } \\
\text { e Studies/ } \\
\text { udies } 71(3), \\
\text { pages. http:// } \\
4102 / \text { hts. }\end{array}$ \\
\hline $\begin{array}{l}\text { Copyright: } \\
\text { (C) 2015. The A } \\
\text { Licensee: AOS } \\
\text { OpenJournals } \\
\text { licensed unde } \\
\text { Commons Att } \\
\text { License. }\end{array}$ & $\begin{array}{l}\text { Authors. } \\
\text { IS } \\
\text { This work is } \\
r \text { the Creative } \\
\text { ribution }\end{array}$ \\
\hline Read online: & \\
\hline 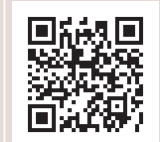 & $\begin{array}{l}\text { Scan this QR } \\
\text { code with your } \\
\text { smart phone or } \\
\text { mobile device } \\
\text { to read online. }\end{array}$ \\
\hline
\end{tabular}

This article is about the 500 hundred year commemoration of the Reformation in 2017. However, the question is to be asked: What should we celebrate in 2017? The article reflects on this question against the background of the ongoing division within Western Christianity. It discusses objectives laid out by Wolfgang Huber in 2008 for the Luther Decade. These objectives focus on the relationship between church and society, and particularly Lutheranthemes such as 'hopelessnesses of life', 'afflictions of faith', 'God's hiddenness' and the 'theology of the cross'. The article demonstrates that the soteriological focal point of BiblicalLutheran theology reflects the assertion that it is only God who, through the belief in Christ, awards freedom and dignity to every human. The Church represents the 'metaphor of a Christian fellowship', which is a fellowship of equals that provides a socio-political impetus.

\section{Reformation jubilees}

What should we celebrate in 2017? Should we 'celebrate' at all? Would it not be more appropriate to observe a Reformation 'commemoration'? That would at least be an indication of the fact that the ongoing division within Western Christianity is no cause for jubilation. But the question that generally arises is whether or not the objectives laid out by Wolfgang Huber in 2008 for the Luther Decade go far and deep enough, or rather whether or not the more deeply rooted and ultimately biblical-theological motifs can actually be received into church and society. The former President of the Evangelical Church in Germany names the Lutheran themes as being those of 'hopelessnesses of life', 'afflictions of faith', 'God's hiddenness' and 'theology of the cross'. He points out that, according to Martin Luther, 'man is in and of himself unfree, a prisoner of sin' and that freedom should, above all, be understood to be 'a departure from the inversion of human existence, as salvation from the disorientations of life, as deliverance from the shackles of sin and death'. According to Huber the basis of this freedom lies therein that 'God bestows on every human the ability to walk upright' so that, consequentially, 'every human is able to bow his knees'. The soteriological focal point of Biblical-Lutheran theology reflects this aspect with its assertion that 'it is only God who, through the belief in Christ, awards freedom and dignity to every human', consequently deducing an unmediated equality of all humankind before God that is experienced on an individual basis. This Church concept is reduced to the 'metaphor of a Christian fellowship', a 'fellowship of equals' that 'also provides socio-political impetus'.

This conglomeration of ideas gives the Luther-Decade-Project the additional appearance of a political project that requires Luther to serve as a prompting source of inspiration to pose the question of meaning, to reclaim an educational-historical relevance ${ }^{1}$ - which admittedly points to Melanchton rather than Luther (Fees 2014:307-329; Schluß 2014:69-89) ${ }^{2}$ - as well as an impact on scientific history - which does not remain undisputed, ${ }^{3}$ or indeed a cultural-historical relevanceand to proclaim an ethicizing Christianity. Such a disposition could - in a derivative way - be called 'Modern Culture Protestantism'. ${ }^{4}$ It is also questionable whether or not the rather sweeping

1.Nevertheless, and at least since Second World War, it has been said about both German states, albeit amidst different parameters, differing conceptions and diverging consequences on both sides, that the education sector has reached a point of 'an almost complete loss of a historically meaningful structure', with 'confessionality' being taken as such (Tenorth 2014:241-245). Nevertheless, a 'cautious, yet in cases of uncertainty nonetheless constantly vigilant, democracy-oriented mindfulness' can for instance be discerned regarding the debates of religious education in the Federal Republic of Germany; it would however require further evidence for the derivation to be made that 'the Evangelical Church can be described as being an institutional, impetus-initialising factor for German democracy' (Schlag 2014:278). As far as the former GDR is concerned, particular mention should be made of the singularity of Evangelical adult education in the sense of a 'church as learning community' with its specific approaches (Rothe 2014:281-294)

2.Friedrich Schweizer (2014:331-347) draws attention to the tensions between the implications of a 'Protestant educational heritage' for the present, amid a difficult mix of a 'religious and ideological pluralism' to which 'Reformation thinking' was 'not attuned'.

3.Cf. the aggravated stance taken towards Protestant monopoly claims on modernism: "The thesis of a "protestant principle" having founded modern science and education faces the same dilemma as Max Weber's thesis on Calvinism or rather a specific Calvinistic school of thought having founded Capitalism. It can, in certain respects, lay claim to a historically selective plausibility, but is, on the whole, certainly not convincing' (Weber 2014:38).

4.Cf. the deliberations by Krech (2013:121-213), according to whom such a milieu is characterised by a co-existence of 'secularists' and 'religious elements', ambivalence, keeping a 'sympathising distance towards the institutional Church', an affirmation of 'social differentiation and structural individualism', as well as an orientation towards 'Kunstreligion' (Art-as-religion). 
claim 'of the Reformation' for 'enlightenment and democracy, individuality and human dignity, religious plurality and tolerance' (Schneider 2011) can be brought in line with historical reality (Lehmann 2013:451-453). ${ }^{5}$ This gives rise to justified criticism as far as the implications of this observance, regarding tourism policy, are concerned (Besier 2013: 422-436).

It is, however, not surprising that during the run-up to the commemoration of the Reformation that has been scheduled for 2017 - in spite of the problematic nature of the historical facts, their historiographic classification as well as their interpretation (Lehmann 2013:453) - this date is bound up with greatly diverging expectations (Lehmann 2012:305-314). In view of the Luther celebrations through the centuries, the conclusion can, on the whole, be reached that, 'All previous Luther jubilees during the past centuries were highly politicised' (Lehmann 2012:299). It is indeed necessary to point out that the Reformation is not merely an event of Protestant Church history and German history in general, but rather a process of Christianity, therefore, elevating it to an event of world-historical significance (Lehmann 2012:9-16, 303, 311f.). From a Roman-Catholic point of view, and even with greater ecumenical open-mindedness and 'approaches to the person of Martin Luther', the 'fact' of the 'schism within the Western Church' remains, posing an ecumenical challenge (Thönissen 2013:437f.). Nevertheless, in the context of more recent Roman-Catholic Luther and Reformation research, it seems possible to locate 'Luther's reform objective in the historically more encompassing domain of Lutheran confessionalisation', opening up the possibility of 'revisiting Martin Luther and the Reformation in a new, Catholic way' (Thönissen 2013:442), and even of an 'ecumenical reception' of Luther (Thönissen 2013:441).

In my opinion the very strong reactions, that the document of the Evangelical Church in Germany on 'Justification and Freedom' (EKD 2014), have elicited from some RomanCatholic quarters suggest that, as far as the question about what should be commemorated or even 'celebrated' is concerned, it is apparent that there remain a number of larger ecumenical stumbling blocks that remain and need to be processed or, if not, removed altogether. The statement alone that 'this jubilee is, for the first time, being jointly prepared by all-Protestant Churches in Germany' is a rather bold one, but can be explained by a conception of the term 'Evangelical Church', based on the Leuenberg Agreement which holds out Church unity as a possibility (EKD 2014:8). It is, therefore, not surprising that the jubilee of 1817 is interpreted as being the date of a 'rapprochement of the two great confessional wings of the Reformation' (EKD 2014:17). These days, references are made under the heading of a 'legitimate pluralisation due to

5.Cf. also Lehmann's (2012:452) extremely critical, partly justified inquiries concernin the history of Lutheranism since 1517, as well as his conclusion: '500 years of the history of Lutheranism since 1517 , as well as his conclusion: '500 years of Lutheranism is certainly not an outright success story that one could point to in 2017 with a sense of pride.' Instead, Lehmann (2012.453) would rather refer to a "success story of Protestantism and, in this context, poses the question about whether or not the latter 'can still be brought into close associanion with Luther at all.' The critical questions Lehmann directs at Lutheranism can, with equal if no greater justification, be directed at 'Protestantism'. its Scriptural conformity' (EKD 2014:99) in order to counter the term 'schism' (EKD 2014:21f.).

\section{The central theme of the Reformation}

Many aspects of the attempts of this fundamental text to revisit the 'central theme of the Reformation' for modern contemporaries can be described as being successful, for instance the emphasis on the exclusive particles (solus Christus, sola verbo, sola scriptura, sola gratia, sola fide) and the interpretation of these with the aid of the keywords 'love', 'recognition and appreciation', 'forgiveness' and 'freedom' (EKD 2014:29, cf. the implementation, pp. 44-93, also p. 98). It has to be stated nonetheless that the repression of the motif of sacrifice in the description of Christ's work is cause for concern (EKD 2014:62). The concept of freedom, even given the differences in perception of this concept between Reformation and modern times (EKD 2014:33), continues to be understood as freedom towards the other, and is consequently used in an equivocal sense (EKD 2014:65). Accordingly - and despite protestations to the contrary Luther's appearance in Worms is being invoked for the 'fundamental value of universal freedom of conscience' so that 'Luther's fundamental belief' corresponds with 'the modern framework of the constitution of the democratic state' (EKD 2014:102). Then it may also be expected that 'the jubilee ... should become a celebration of society as a whole, and of the secular state' (EKD 2014:105). Furthermore, defining the relationship between congregation or church and ecclesiastical ministry appears to be particularly questionable to me, seeing that the latter should apparently only exist 'for the sake of order' (EKD 2014:91).

Wolfgang Thönissen, the Executive Director of the JohannAdam-Möhler Institute in Paderborn has, albeit with unusual vehemence but with some justification, described 'this Protestant programme' as not being compatible 'with the ecumenical programme. ${ }^{6}$ Thomas Söding, a Roman-Catholic New Testament scholar in Bochum, has concluded, from his critique that the fundamental text also fell short of offering 'a base for a serious discussion with Catholic theology', that an 'ecumenism of profiles', as called for in 2005 by Wolfgang Huber, the former President of the Council of the Evangelical Church in Germany (EKD), should rather be replaced with the model of an 'ecumenism of strengths' (Söding 2014:353). The Erfurt Luther Symposium, hosted by the Johan-AdamMöhler-Institute and the Faculty of Catholic Theology at the University of Erfurt, paid tribute to Martin Luther as being a 'Reform Catholic'. ${ }^{7}$ It seems to me that here, too, lie the beginnings for a Reformation commemoration with Concord-Lutheran ecumenical intent.

Originally a denotation imposed by others, the term 'Lutheran' becomes one of self-designation, also in the sense of an inter-Christian differentiation. But what is the greatness

6.Ökumenische Information 28, 08 July 2014, p. 3.

7.Ökumenische Information 37, 09 September 2014, p. 3. 
of 'Lutheranism'? During the confessionalisation processes of the 16 and 17th centuries (Rublack 1992; Schilling 1986) ${ }^{8}$ an emergence of varying church-institutional forms can already be discerned, despite the homogenisation tendencies effected by the Formula of Concord (Kolb 2011), if one only looks at the Holy Roman Empire of the German Nation in various territorial church developments (Heckel 1983; Koch 2000). Standing outside of this are national churches in Scandinavia, for instance, but also groups and minorities of Lutheran orientation that are under pressure.

The notion that 'Protestantism' has brought forth the formation of the modern-day scientific approach or has affected it in a particular way has come under fire of late as being 'a Protestant-Lutheran master narrative' (Weber 2014:36). It should, in any case, be borne in mind that the term 'Protestantism' carries with it the risk of a hasty unification where differences are concerned about theology, confession, denomination or types of devotion (Joas 2013:490). ${ }^{9}$ By contrast, claims, about the impact on scientific history in the sphere of influence of Calvin and Calvinism, continue to be made (Balserak 2013:91-103), not least for the early period of the Netherlands (Frijhoff 2014:107-129). The 'Protestant Reformation' has been used in order to serve at least as a general framework for the development of natural philosophy, medicine and astronomy (Grell 2014:208).

Amongst the 'ingrained interpretive paradigms of European history' is also the assertion 'that Calvinism is said to have affected the promotion of democracy, while Lutheranism is said to have strengthened the belief in authority' (SchornSchütte 2013:17). This view needs to be modified at the very least, as the 'doctrine of the three estates' (Drei-Stände-Lehre) of Lutheranism led to the restriction of authority, and the 'resistance debate' in the Reich 'did not break off' (SchornSchütte 2013:39) after the Peace of Augsburg. It has been proven for quite some time that particular subservience to authority does not apply to the Lutheran court chaplains, at least not to those of the first few generations (Sommer 1988, 1999). It must be emphasised in this regard that the more recent right to resist was 'invented' and first propagated by Lutheranism in the middle of the $16^{\text {th }}$ century', hence, Lutheranism cannot simply be defamed as being a 'doctrine of subservient subordination' (Joas 2013:492; cf. Reinhard 1993:53-69, 2004).

The question about whether or not more valuable insights can be gained with the concept of a 'Lutheran Confession Culture' might be raised (Kaufmann 2006:9). The concept does at least achieve the identification of 'confession as [being] Lutheran' practise, thereby representing an open process. However, the determination of a Lutheran identity does thereby tend to remain underexposed. One can nonetheless discern a specific impact of Reformation theology on the fine arts, for instance the thematisation around the Lutheran basic formula of 'Law

\section{Where the Roman Catholic Church is concerned, cf. Schilling (1995)}

9.A section of the cited literature below is most definitely lacking in this regard; it is for this reason that I regularly put the term in inverted commas. and Gospel' (Reinitzer 2006). It is and remains undisputed that the Bible and Hymnal, in the way that they have become determinants for piety and worship during the Lutheran Reformation, have, 'during the subsequent period, defined Christian culture as a whole, and across all confessional boundaries at that'; this is exemplified by the names of Paul Gerhardt and Johann Sebastian Bach (Wolff 2014:350).

Where constitutional law, pertaining to the church and state, is concerned, the Peace of Westphalia of 1648 - constituting the first large-scale attempt at a European framework for peace (Bußmann \& Schilling 1998; Dickmann 1997) - initially safeguarded the unity of the Reich, characterised by the dissimulation which codified the relative legal validity of multi-confessionality (Koch 2000:328-332). During the further course of European history, ${ }^{10}$ but especially in the Holy Roman Empire of the German Nation and its territories, this religious plurality played a determining role in the shaping of diverse and also collective mentalities and regional identities (Schilling 1999, 2007).

\section{Luther interpretations up to the 20th century - An outline}

Early historical receptions of Luther in the 16th century already reflect historical-theological interpretations, for instance when Luther is portrayed as being a prophet, teacher or hero (Kolb 1999), partly in a mythological mould, partly in a kind of confessional canonisation as witnessed in the Corpora Doctrinae, and absolutely in competition with Phillip Melanchthon (Koch 2000:211-218). Luther's authority is defended in the Apology of the Formula of Concord (1584) over objections from crypto-philippistic quarters; for their part, the Calvinists accordingly dispute Martin Luther's prophetic and apostolic 'office'. Such stylisations result in a development of tendencies towards a monumentalisation and stereotyping of Martin Luther, which superelevate and paralyse the historical Luther (Kolb 1999:114). Pietism and Enlightenment are, for the most part, not interested in Martin Luther as teacher of the Church, in terms of a Lutheranism informed by the Formula of Concord, even though Philipp Jakob Spener and the first-generation Lutheran Pietists laid legitimatory claim to Luther (Brecht 1993:293, 373, 469).

For the self-assurance of the Lutheran territories (for their elites and - at least in parts - their people, and even before the Thirty Years' War as well as after it) significance was afforded to the Reformation jubilees. They reveal in each case the church and religious position(s) that were in need of legitimatory strengthening. The centenary of the Reformation was interpreted in the light of Heilsgeschichte (Schönstädt 1978; 1982a:5-57); Luther is assigned a 'salvific over-dimensional quality', by virtue of which the Reformer from Wittenberg is

10. Not taken into account in this portrayal is the impact of the Wittenberg Reformation beyond Europe's borders, and the development of Lutheranism in Africa, say, or Asia and Latin America; cf. however Ludwig (2013:282), who draws attention to the question about when and by way of which transmission belts certain Lutheran mages were imparted, and how these were transformed via various processes of appropriation and interaction'; for North America (cf. Wellenreuther 2013 309-330). 
said to have rehabilitated Scriptures, brought the Doctrine of Justification to light again and corrected sacramental theology (Schönstädt 1982a:47-49). By way of response to the Roman Catholic Church's contestation of Luther's legitimisation, a virtually direct calling to the position of Reformer was assigned to him by the opposite side (Schönstädt 1982a:55), as it was not least a matter of 'safeguarding the dogmatic claim to truth of German Protestantism' (Schönstädt 1982a:57). As the Wittenberg speeches and sermons of 1617 show, it was about nothing less than the 'legitimisation through history', in which Wittenberg styles itself as being 'Salem' (Ligniez 2013:53-66), or Strasbourg, where it expedited 'its solidarity with Saxon Lutheranism', contrary to its own Reformation history and by way of profiling itself against the newly-founded and imperially privileged Jesuit College in Molsheim (Reichelt 2013:87).

One to one-and-a-half centuries later the historicaltheological interpretation of the Reformation was still very present in its objection of and opposition to the papacy, as the papal church was still being portrayed as the 'apocalyptic world tyrant'(Römmelt 2013:141-177; Schönstädt 1982b:108). The image of Luther was in accordance with this, where his person was interpreted as being the fulfilment of the prophesy in Revelations (Schönstädt 1982b:114), or rather as being the 'sun' of 'religious enlightenment' (Römmelt 2013:174). Within the ranks of the last representatives of Lutheran Orthodoxy, the Reformation jubilee of 1717 was utilised to once again 'demonstrate the unity of Lutheranism' (Cordes 2013:89-103). However, one also comes across laments about 'a desolate condition of the Evangelical Church', especially in Electoral Saxony, together with the contradicting appeal to adhere to the traditional Lutheran faith. The latter were to no small degree topical, as the Elector had converted to Catholicism twenty years previously, and the Electoral Prince had changed his confession very recently to this time (Ligniez 2012:42).

Pietism 'historicises' Luther 'as well as his doctrine' and predominantly perceived him as being 'homo religiosus', who was 'undoubtedly one of a kind', beyond whom history admittedly extended and who, in the consciousness of the development of piety, 'is recording something new and seminal into the annals of history' (Drese 2013:114). By referring to Luther's preface to the Epistle to the Romans, by emphasising the priesthood of all believers, or by referring to Luther's preface to the German Mass, the Lutheran Pietists were, at least in the beginning, admittedly striving to maintain continuity with the Wittenberg Reformation, especially where the Doctrine of Justification was concerned; however, the theological-existential concern shifted towards a 'regeneration of the justified', or rather towards implementing and safeguarding the existential turning point (Brecht 1993:374-378, 463). Studies were now geared towards practical relevance 'within the framework of a holistic practise of piety' (Wischmeyer 2014:50).

Enlightenment turned its intrinsically theological motifs into those of anthropology and psychology (Lehmann 2012:297), thus, executing a 'secularisation of the image of Luther', during which central theological concepts of - but not only Luther were lost: humanity and ideal, nation and people are the guiding interests that supersede theology and church (Hensing 1984:2-4). Accompanying this was a change on the view of Luther towards 'the interdenominational'. A paradigm shift occurred in the writing of Church history which now had a 'science specific association with the past', inasmuch as the 'Protestant theologians were compelled, to some extent, to develop new legitimisation interpretations for the Reformation which had to prevail before the judgement seat of reason' (Fleischer 2013:125). Enlightenment is, according to the 'teleology of progress', consequently 'the driving force behind an improvement of religion and science that extends beyond the Reformation' (Fleischer 2013:137). This was consistent with an increased emphasis on practical relevance in progressive concepts of theological studies, albeit as opposed to Pietism - sustained by a 'solid, intellectual education' (Wischmeyer 2014:59). These concepts comprise 'a stronger individualisation, subjectivisation and above all hermeneutical humility in the sense of religious tolerance' whilst simultaneously exceeding 'former confessional selflimitation'. A separation of Christian and 'secular educational contexts' subsequently tends to occur (Wriedt 2014:189).

In North America, during the 18th century, the Lutherans were mostly in the minority but were facing greater difficulties where the (re-)organisation of the church was concerned, not least because of the new geographical, societal, governmental and religion-political contexts. On the one hand, the North American pathos of liberty and a new beginning served them as a guiding principle for a new contextualisation; its legitimacy was, however, underpinned by its close historical ties to Luther and the Reformation (Flügel 2013:179-211). ${ }^{11}$ For the Lutherans of predominantly German origin the Reformation jubilee of 1817 - a 'minority phenomenon' in the United States (Flügel 2012b:71) - acted as an orientation within the new context, but with varying outcomes. It became either an expression of the ability to connect 'with other Protestants', or emphasis was placed on 'Lutheranism as an autonomous denomination in a Protestant environment' whilst 'simultaneously stressing linguistic and religious autonomy' (Flügel 2012b:99). The latter still applied in the middle of the 19th century to the Saxon emigrants who subsequently formed the Missouri Synod. ${ }^{12}$

In the 19th century (Wendebourg 2011:270-335), and originating from Herder, the 'German Luther' (Hensing 1984:7-9) increasingly turns into an icon of not only national but nationalistic self-assurance, the incense of which is burnt as offering to this idol in 1817, 1883, 1917 and 1933. Thus, Leopold von Ranke portrays Luther 'as an organ of a higher office and executor of a transpersonal mandate' (Hensing 1984:7); he becomes 'the embodiment of national mission and national spirit' (Hensing 1984:7). This 'ideologisation of the

11.Similar sentiments were still held in the 19th century by the Saxon emigrants, who went on to form the Missouri Synod.

12.Cf. the historicising and assuring title of a portrayal dating from the middle of the 20 th century (Forster 1953), but also the instructive study by Barnbrock (2003). 
image of Luther' (Hensing 1984:8) is consolidated by linking it to the commemoration of the Battle of Nations and the posting of the theses (1817) and, with Luther's 400th birthday in 1883 , by interpreting the Reformation as being the pivotal factor in setting the course for the founding of the German Empire in 1871, according to Heinrich von Treitschke who extols Luther as being the 'leader of the nation' (Hensing 1984:9). Some of the Reformation sermons held at the 300-year anniversary celebrations at the beginning of the 19th century already bear the signature of at least posited 'liberty', 'progress' and 'tolerance', but also 'free will', 'civic virtue', and 'immortality', so that this kind of 'Protestant' theology regresses, especially theologically, to pre-Reformation positions (Von Meding 1982:144). On the Roman-Catholic side, by contrast, the Reformation was, despite certain ecumenical attunements, 'on the whole, due to its divisive nature, not perceived as being beneficial' (Wolter 1982:173). It is noteworthy that in Frankfurt, Main, for instance, there is a predominance of 'patriotic and domestic virtues' in prayers (Wolter 1982:171). A new 'Protestant' selfawareness also began arising within this context. The third secular celebration of the Reformation already has national overtones, not least the result of a suggestion by Goethe to observe this commemoration as a feast 'of all Germans'; even so, and probably as far as the state was concerned, 'confessionpolitical facilitation was still advised in 1817' (Lehmann 2012:23). Moreover, a pluralistic reference to and utilisation of Luther, depending on the theological position, can now be discerned (Lehmann 2012:24; Wischmeyer 2013:304).$^{13}$ The secular celebration of the Confessio Augustana in 1830 effected the already existing respective theological orientations - the 'post-Kantian rationalism', but also the 'revivalist movement and Neo-Lutheranism' - to 'experience a culminating intensification', but always with 'legitimising back reference'. This was whether or not they viewed Luther as being the 'archetype of Enlightenment' or that they regarded the theology of the Augsburg Confession as legitimisation for the 'experience of sin and grace' of the revival movement, or that they utilised him in his 'confessional identity-giving role' for 'Neo-Lutheranism' (Hund 2013:252). In 1883, and by imperial decree, all Evangelical Churches were compelled to hold Luther celebrations; however, the jubilee, 'with its attempt at elevating Luther to the great integration - and identification figure of all Germans [remained] full of uncertainties and ambiguities' (Lehmann 2012:76). As far as Heinrich von Treitschke was concerned, Luther constituted 'the eternal German' (Lehmann 2012:126-137). In 1883 in North America, on the other hand, Luther was, transdenominationally speaking, rather considered to be a trailblazer for the modern age, a viewpoint that should change radically before 1917 (Lehmann 2012:94-109). Towards the end of the 19th century and 'within a saturated nation' (Kranich 2012:143), Luther serves as the 'classical representation of the German spirit and German morality'. In this his religiosity is viewed as being a genuine expression of just such Germanness which is, as such, absolutely in competition with Catholicism and celebrated by a more 'Protestant bourgeoisie', despite the inherent tensions in this milieu (Klän 1999:145-151). ${ }^{14}$ The Luther jubilee of 1917 took place amidst the seemingly unending and undecided First World War (Maron 1982: 1-46). These celebrations were marked by an emphasis on nationality and by championing an ethos orientated towards a 'German Luther', imbued with heroism (Hennings 2013:217-237). Being almost naturally different, that is to say not focused on nationalism, the Reformation commemoration of the Reformed Church took place during the penultimate year of the War (Ulrichs 2013:238-261).

\section{Luther renaissance and Luther jubilees during the first half of the 20th century}

A new academic reflection on the Reformer from Wittenberg only begins with the 'Luther Renaissance', justifiably assessed as being 'the other departure' after the First World War, alongside the dialectic theology (Assel 1994). Contrasting as yet with cultural Protestant interpretations (Gäbler 1984:187-197) the Luther Renaissance begins to develop new approaches that, like Ernst Troeltsch (Gäbler 1984:189), emphasise Martin Luther's 'championing of the individual' or, like Reinhold Seeberg, interpret the relationship with God as being 'personal, spiritual, divine', accordingly, the 'Reformation is ... the German understanding of Christianity' (Gäbler 1984:193). According to Karl Holl, 'religion', as taught by Luther, turns into 'conscience religion in the most pronounced sense of the word', rooted in God's actions of love and wrath, which 'are inaccessible to human reason' (Gäbler 1984:195) but which are consolidated in the 'encounter with God' (Gäbler 1984:196). Holl significantly views the experience of Germany's defeat in the First World War as being a judgement of God (Pöder 2013:191-200). According to Rudolf Herrmann, justification is articulated by faith as the basis for its certainty, which is being expressed as simul iustus ac peccator within the context of self-awareness. He takes up the Lutheran distinction between Law and Gospel, or rather between person and conduct, in such a way that the believer's feelings of inadequacy concerning his or her own conduct under the threat of the law is converted into the lamentation that remains focused on God (Assel 1994:483-486).

The Swedish Luther Renaissance constitutes its own 'encompassing awakening', 'similar to the dialectic theology on the continent, butwithoutbeing as radical in its renunciation of problems pertaining to previous epochs' (Lange 2005:246). A rejection of a 'nationalistic Luther interpretation' (Lange 2005:264) can be observed, coupled with a 'national church' ('Volkskirche') model, admittedly with national connotations. Nathan Söderblom famously gained relevance with his concept of 'evangelical catholicity' to which he deemed Lutheranism to be particularly obligated (Lange 2005:265), and at the core of which he regards 'the indefensible personal relation to God', by which he admittedly risks voicing his 14.Cf. for the local history of Dresden, the summary in Kranich (2012:140). 
opposition to 'the non-institutional mediation of the Church' (Lange 2005:268). The impact of Billing and Söderblom on Swedish theology cannot be underestimated; the common feature of this Luther interpretation and reception is the 'dualistic' reading of Luther's theology (Lange 2005:270). In Norway, a prime example of a critical, resistant reclamation of Luther's 'Two Kingdom doctrine' is finally provided by Eivind Berggrav, who affirms the safeguarding of the sanctity of the law against the demonic distortion of political power, thereby making it seem possible to 'save the honour of the political theology of Lutheranism' (Lange 2005:273). It cannot be overlooked, however, that in Sweden, too, the various Reformation jubilees were exploited for the purpose of a Swedish 'separate path', to wit, with regards to ecumenical as well as political objectives (Jarlert 2013:262-271).

That this occurred after the onset of National Socialist rule in Germany under the sign 'DeutscherLuthertag 1933' (German Luther Day) constituted a deliberate orchestration, but did ultimately not prevent the failure of this venture to send out the 'signal of an Evangelical awakening and solidarity'; the Sportpalast-rally under the motto: 'Die völkischeSendungLuthers' (Luther's national mission) virtually drove ecclesiastical conflicts in the struggle between church and state in Germany (Buss 2013:272-288).

The Luther Day in Dresden (Willenberg 2012:195-237) may serve as a good example: it was initially postponed resulting from upcoming elections in order to avoid any confessionpolitical prevalence where the Evangelical section of the population was concerned. It was adjourned yet again as a reaction to the Sportpalast-rally and downgraded to serve merely as a platform for the inauguration of the new bishop. The event nevertheless availed itself of Luther for National Socialist purposes (Lehmann 2012:176-188). A blending takes place of 'national consciousness and ethnic thinking', orderof-creation theology and race theory, as well as a theological legitimisation of war (Jasper 2013:383, 385).

It is interesting to note that Lutheran publication organs in the USA, both of German and Scandinavian provenance, were clearly inclined to defend the National Socialist state against attacks from the 'liberal press' in the USA (Ericksen 2013:319-334). By contrast, reactions from Roman-Catholic quarters remained the exception (Pilvousek 2013:335-346).

At the University of Halle-Wittenberg the Luther Renaissance and Max Weber's theses of economic theory were reflected, in the context of the Reformation celebrations that were held annually between 1927 and 1941, and under the terms of the Weimar Republic; whereas a prevalence of GermanChristian mediation attempts can be discerned during the first years of National Socialist rule and anti-Roman-Catholic and nationalist tones in the later years (Kranich 1999:171-193; Reichelt 2012:145-169). A similar exploitation of Luther was also involved in the name-giving for the University of HalleWittenberg, not least against the background of the 'Dehn case' (Hoenen 2003:161-180). In this instance Luther's name was used 'for a German-national, ethnic, anti-Western and at the same time anti-democratic tradition' (Stengel 2013:289318; this is being disputed by Reichelt 2012:154-158, 168). This also included an attempt by the Church to legitimise the National Socialist accession to power with a comparison of 'Luther and Hitler' (Lehmann 2012:151-159; Preuß 1933), or, up to the annexations of 1938 and 1939 and the start of Second World War, to utilise the Reformer as the 'crown witness for Hitler' (Lehmann 2012:160-175). ${ }^{15}$

\section{The Luther-image in the literature of the 20th century}

It would be highly interesting to trace the Luther-image in the German literature of the 19th and 20th centuries (Aland 1973; Laufhütte 1984:27-57). Suffice it to say that Nietzsche's Luther-image is ambivalent: on the one hand the Reformer from Wittenberg appears as a 'representative of German culture' (Ibsch 1984:80), on the other as a 'reactionary revolutionary' (Ibsch 1984:81), as the Reformation has apparently 'destroyed the precious elements of the Renaissance' (Ibsch 1984:82). In later years Nietzsche rejects Martin Luther as being a 'dogmatist who does not share a scepticism in finding the truth, something that is of crucial value to Nietzsche' (Ibsch 1984:83). It is merely Luther's achievement in translating the Bible that he still regards as being exemplary (Ibsch 1984:84). A long-term effect of this approach can be detected, amongst others, in the works of Stefan Zweig and Thomas Mann. Where Zweig is concerned, Luther is the 'fantastic man of action', totally caught up in his black-and-white thinking, almost a 'werewolf, possessed by a tremendous fury, uninhibited by deference or righteousness' (Van Ingen 1984:101), a kind of 'blood and soil Luther' (Van Ingen 1984:99) as it were. According to Zweig's self-identification, Luther's antitype is Erasmus who is a 'representative of the intellectual in an era characterised by mass hysteria'. In comparison Martin Luther is being attributed with downright 'Hitlerian' traits (Van Ingen 1984:95; cf. Lehmann 2012:100-109). With regards to Thomas Mann, who rejects this antithesis, the Luther-image does, however, remain an ambivalent one; he is the embodiment of Mann's beloved 'German' after all, the progenitor of 'German inwardness' (Van Ingen 1984:105) towards which he makes a virtual 'declaration of love', whilst he does not precisely discern a (German) alternative in an Erasmusoriented humanism (Van Ingen 1984:108). This occurs even though he does observe, within the 'Lutheran' features of German history - albeit not necessarily so - the existence of 'the pathogen' that leads to perdition (Van Ingen 1984:106), that is to say misdirected special gifts, as a connection from Luther to the western European idea of freedom in the political sense could not be attained (Mannack 1984:170). A more radical stance is taken by the critics of the 20th century who consider Martin Luther to be the forerunner of German fascism, like Erich Fromm for instance, who misconstrues Luther's concept of faith as having 'much in common ... with

15.Cf. the critical analysis of the hypothesis that Luther paved the way for Hitler (Siemon-Netto 1993). 
the principle of complete submission by the individual to state and "Führer"' (Mannack 1984:179).

From a Marxist point of view (Lehmann 2012:257-270) the Reformer was, for an extended period of time, construed as being a 'prince's servant' who had betrayed the peasants and their revolution. Only in the late phase of the GDR, and in the context of the 'heritage' discussion, was Luther reintegrated as one of the 'traditions that shaped national identity'. In doing so, Luther's Reformation was viewed as a 'platform' which allowed the 'pre-Reformation popular movements, insurrections and conspiracies ... to consolidate into a broad movement' (Laube 1983:4). The 'popular movement' did, however, take on a life of its own, even though 'Luther's Reformation' had laid the 'key foundations' (Laube 1983:5). Thus, the Reformation becomes the catalyst for an 'epoch of early bourgeois revolution' (Augustijn 1984:225) with a definite religious base. A 'new understanding of the relationship between God and Man' (Augustijn 1984:227) was said to have 'initiated a progressive development' (Augustijn 1984:228). In view of the Marxist Luther-image one can, thus, justifiably speak of a 'dual, grotesque exploitation of Luther' (Augustijn 1984:268; cf. Lehmann 2004:501-514).

\section{Luther jubilees during the second half of the 20th century}

A distinct feature of the 450th Reformation Jubilee in 1967 was that it 'reclaimed and reinterpreted Luther as heritage', admittedly without 'political actualisation' for the most part and at least where 'the voices of the Church in East and West' were concerned. This can, at the same time, be regarded 'as a huge media event', as 'ecumenical reminder due to the Catholic discovery of Luther' and 'as a German-German jubilee' and even as 'celebrations of church and state in the GDR' (Ringshausen 2013:373). A genuine encounter between church historians and Marxist historical research did, however, not take place (Ringshausen 2013:385). The latter did, however, begin to appreciate the 'global significance' of Luther's Reformation, which constituted 'an important contribution by the German people towards the history of Europe and mankind' (Ringshausen 2013:394). The SED (Socialist Unity Party of Germany) and churches in the GDR 'pursued opposing, sometimes conflicting objectives concerning the Reformation Jubilee' (Flügel 2013:249). The same held true for 'interpretational sovereignty' and 'organisational sovereignty' with regards to events, particularly in view of the fact that the commemoration of the Reformation was approximately at the same time as the 50th anniversary of the October Revolution (Flügel 2013:257f.). From a theological point of view the failure to reformulate the theological core message of justification during the Fourth Assembly of the Lutheran World Federation cast a shadow on the festivities (Ringshausen 2013:380-382). The theme of renewal pervaded many comments, reflecting the respective mood, especially in sections of West German society on the eve of 1968 (Ringshausen 2013:385-389). For the Federal Republic of Germany (before 1989) it can be argued that, after Second World War, an endorsement of democratic principles prevailed amongst Lutheran theologians, too, who had knowledge of the boundaries of the state, the significance of the separation of powers and the political responsibility of Christians, even though they were still hoping for a 're-Christianisation of German society' during the first post-war years (Jasper 2013:388-393). It was only later, with the paradigm of the Church's 'public contract', that a change in position towards society and state took place (Jasper 2013:394f.). As far as the GDR was concerned, system-critical concepts and those that transcended practical politics wrestled with one another in defining the Church's position, to the point of the 'repudiation of the institutional self-interest of the Church' (Pollack \& Richter 2013:406).

Special attention should be awarded to the fact that the Roman-Catholic public and media studies now also began to pay tribute to Luther, something which would admittedly have been 'inconceivable without the (Second Vatican) Council' (Henze 2013:347-372). Thus, Hubert Jedin was able to 'acknowledge all that is great in Luther', even though he still considered the Reformation of the 16th century to be 'illegitimate' (Henze 2013:353f.). Others, however, sought to understand him as a Reform-Catholic (Lehmann 2012:30-32) and, even more so in the light of the (Second Vatican) Council, to 'closely align the desire for renewal with efforts towards church unity' (Henze 2013:358). Thus, within the context of Martin Luther's 500th birthday, this led to first beginnings towards an 'ecumenical interpretation' of the Reformer from Wittenberg. Luther was 'an immensely strong impetus to be experienced, and ecumenical stagnation to be overcome in key areas' (Manns \& Meyer 1983:13). The fundamental confession of Lutheran Reformation, the Confessio Augustana from 1530, had previously been acknowledged in Lutheran and Roman-Catholic discussions as being the 'confession of the one faith' (Meyer \& Schütte 1980) and, as a consequence, Pope John Paul II spoke of a 'consensus in central fundamental truths' (Rahner 2013:400-411). Peter Manns even dared to refer to Luther as a 'father in faith', even though he played Luther off against Melanchton and the confessionalisation in his wake (Manns 1980, 1985; Manns \& Loose 1982:219; cf. Thönissen 2013:442). This is merely an indication of the fact that it was not only the Roman Catholics who had changed their view on Martin Luther, at least amongst a section of those who had studied theology (Pesch 2013:449-483). It was rather that, as documented by the study 'Lehrverurteilungen - kirchentrennend' (The Condemnations of the Reformation Era, Do They Still Divide?, Lehmann \& Pannenberg 1988), an entirely 'new hermeneutic method: differentiated consensus' emerged (Rahner 2013:404).

On the Protestant side, the Luther celebrations of 1983 were characterised by an all-Protestant, even all-German state of mind; the relatively high attention afforded by the political sector to ecclesiastical processes in East and West Germany, and the cooperation of state and church representatives, is remarkable. In a sense the churches acted as a 'Protestant fellowship of remembrance' (Lepp 2013:412-421). This 
occurred, despite efforts by the SED to prevent schedule conflicts of party and Church events (Flügel 2012a:267). In some cases also occurred against the 'historical-political' intentions of the GDR leadership, which busied itself with an 'almost martial exploitation of Luther in the domestic and foreign policy objectives of the GDR ... in order to gain international recognition for the GDR, especially in the countries of the Western world' (Lehmann 2012:232256, 271-280). These ambitions did, however, for the most part, end in 'failure', as even the transformed image of the Reformation was accepted neither by the people of the GDR nor by the SED cadres (Flügel 2012a:284). The churches in the GDR, on the other hand, strove for 'establishing identity and strengthening the faith of the congregations'; they were obliged, however, to endure the 'balancing act between a battle for self-preservation against the usurpation attempts by the State party ... and a struggle for their own authenticity' (Flügel 2012a:268, 275). They did not always succeed, seeing that there existed an 'increasing willingness to adapt on behalf of the Evangelical Churches' in view of the power structures and decline in membership that seemed to suggest this, and seeing that Karl Barth - admittedly not necessarily a Lutheran - had, with his 'Letter to a Pastor in the GDR' in 1958, bestowed a virtually theological consecration on the minority situation (Pollack \& Richter 2013:418f.). This was accompanied by a 'socialism-related' positioning within many member churches of the World Council of Churches (Pollack \& Richter 2013:423) which favoured a climate in which the churches in the Soviet domain were able to function with a certain latitude (Goeckel 2013:429-445).

\section{Lutheranism's viability in the light of modern issues}

The Morphologie des Luthertums by Werner Elert ([1932] 1965) probably constitutes the most consequential, if not entirely unproblematic attempt to 'advance from the periphery of impact to a theological approach to church organisations' in an interconfessional manner; he executes this by making a fundamental 'distinction between dynamis and form' (Elert [1932] 1965a:v). For Elert, Lutheranism is not 'a once-configured and concluded variable, but rather one that finds itself living out its history' (Slenczka 1999:148). Interdenominationally, the 'confessional dynamis' is in 'independent competition with 'extracanonical motifs' which, 'in the course of enlightenment', is threatened by the 'loss of the Evangelical approach' (Slenczka 1999:149). He goes on to say that it was only in the 19th century that a 'Lutheran restoration' occurred, inducing the 'Evangelical approach' to 'generate entirely new forms of expression', right up to 'sociology and ideology' (Slenczka 1999:150). Notger Slenczka (1999) has concluded that

for Elert, it is not only a question of depicting Lutheranism's dogmatic, Lutheran, ideological and social forms of realisation emanating from its religious centre, but rather that this depiction is shared by an interest to reach the Modern Era by means of a positive determination of the relationship between Lutheranism and its centre, the Doctrine of Justification, in such a way that this centre itself becomes an entity of critique of the Modern Era. (p. 153)

According to Elert, an 'indissoluble fusion of the historical form of Lutheranism with German culture' initially occurs, but also 'with other nationalities' (Elert 1965b:131), as he tries to demonstrate with Hungary (pp. 169-189), the Slavonic (pp. 190-208) and Baltic (pp. 208-214) peoples, Finland (pp. 214-223) and the Scandinavian nations (pp. 226-250). In this context even the 'development of German Enlightenment towards German Idealism via the German national literature' should be seen as 'a phase in the history of Lutheranism. It is the history of its secularisation' (Slenczka 1999:227). This point of view culminates in the statement that 'Germany's intellectual history is, on the whole, a long-distance effect of Lutheranism' (Slenczka 1999:227). According to Elert, the Doctrine of Justification, thus, fulfils a 'generative function ... for the worldview of Lutheranism' (Slenczka 1999:244) in which the 'facts' of what Elert calls 'natural knowledge of the world are [sic not] negated' (Slenczka 1999:244), but in such a way that 'natural world orientation is affirmed by objecting to it' (Slenczka 1999:244) seeing that it is defined as being the 'antithesis of the God-experience of the Gospel' (Slenczka 1999:246). An inconsistency in Elert's concept can thereby neither be overlooked nor cleared up, namely that 'the construal of mankind's natural situation within the inescapable antithetics of the ... claim to liberty and heteronomy as an experience of God is only made possible by the Gospel' (Slenczka 1999:351). This, according to Elert (1965b:465), also applies to the field of social ethics, seeing that the Church, 'in being faithful to its mission, proclaims the Gospel in antithesis to all worldliness and all ethical contentedness'.

In 1934 and 1936, and in clear contrast to his colleague in Erlangen, Hermann Sasse cautioned against three misconstructions of the Lutheran Reformation:

Lutheranism itself ... does not respond [sic to the question: What is Lutheran?]. It is unable to give an answer to those who inquire after its essence; it is a mute concept. It is a different matter, however, if we inquire after the Lutheran Church. The Evangelical-Lutheran Church is not an idea, it is a reality. It is not mute, it speaks. (Sasse [1934] 1936:12)

He further states that the heroic misconstruance culminates in hero-worship and apotheosis of Luther, which does indeed extend right into the Luther Renaissance and during which a personalistic view of the Reformation prevails. The person of Luther does, however, recede into the background soon after the first generation, only to be heroically exaggerated in the 19th century as being the 'hero from Worms' or 'God's man-at-arms' (Sasse [1934] 1936:3136). According to Goethe, who understood the Reformation to be a liberation and advancement of culture, historicalcultural misunderstanding construes the Reformation as constituting a date of intellectual history in general. Luther on the other hand, according to Sasse, poses an obstacle to the 'modern' sense of self (Sasse [1934] 1936:36-48). This national misconstruance apparently sees Martin Luther as 
being the 'protest of Nordic man against the piety and the ecclesiastical system of Roman Catholicism' and aims at a German national church, which had arisen during the "Third Reich'. To Sasse this is one of 'the most dangerous heresies' (Sasse [1934] 1936:49). In this respect the Reformation and the theology of Martin Luther are deemed to be universally and ecumenically relevant, even where resistance of his doctrine is concerned. The latter, in the form of the Doctrine of Justification, constituted 'the renewal of the Church through rediscovery and renewed proclamation of the pure doctrine of the gospel of the forgiveness of sins' (Sasse [1934] 1936:71).

Notger Slenczka (2004:188), in his critical reception of Elert and others, has attempted to determine the relationship of 'Lutheranism and the Modern Era'. In doing so, he identifies 'Justification' as constituting 'an imposition on a new understanding of self'. This included 'the profiling of this Lutheran understanding of subjectivity against the modern concept of the subject', as it was a matter of nothing less than 'a new determination of identity and the subject's understanding of self.' Slenczka (2004:190) calls this the 'modern foreignness of the Lutheran Doctrine of Justification'; the connective according to Slenczka (2004:181) lies 'in understanding the subject's indefensibility pertaining to its prevailing certainty of truth on the one hand, and in embracing and acquiring salvation on the other'. Slenczka (2004:183f.) thereby ascribes enduring validity to 'Justification' as being 'a purely external declaration of righteousness of man before God that remains external', in the sense of an 'imputative doctrine of reconciliation and justification' but admittedly also, in this interpretation, to the basic difference of the Reformation's 'fundamental insights ... from the Modern Era' (Slenczka 2004:192).

In relation and relevance to the modern-day generation, and in my assessment, Oswald Bayer's (2004) view of Luther and Lutheran Reformation lends itself to be sketched into this relationship picture that is filled with such tension. In his view Luther remains the theologian who, 'in the light of his own indigence', proceeds to 'gain open space' from the 'inexhaustible abundance of Scripture' (Bayer 2004:66). The Word of God, consolidated in the assurance of absolution, embarks on a 'course of church ... and world-history' (Bayer 2004:69), not without being challenged but ultimately triumphant. For therein lies the presence of God, who looks after us and administers to our needs, so that we are 'constituted' in the Word of God (Bayer 2004:77). God the Holy Spirit has sovereignly bound Himself thereto and, to wit, to 'the spoken language and literal Word in the book' of Holy Scripture (Bayer 2004:84). We are, therefore, being expounded in our existence, and precisely therein lies the 'idiosyncratic passivity of our experience of faith' (Bayer 2004:150), which culminates in the Christ-experience pro me

the communicative Being of Jesus Christ itself, in which the Triune God assigns and gives Himself in the 'incarnate Word' with the sacraments of Baptism and Holy Communion, as well as with every sermon that is in accord with these sacraments ... [creating an] ... excentrical way of being ... [for a Christian because the Gospel, as] ... the second, decisive, conclusive Word of God [speaks] for me. (Bayer 2004:151-152)

Bayer dodges the subject of freedom in its temporal dimensionality in such a way that he conceives of that which is specifically Christian in the concept of freedom as being the 'liberation from the iniquities of the past and the fear of the future' (Bayer 2005:297). He presumes a characteristic of modernism to be 'the coherent subject that is in control of itself' and that can escalate itself to a 'pathos of individuality and omnipotence' (Bayer 2005:299). He identifies 'the feeling of a dissipated individuality' as a characteristic of postmodernism, combined with the risk of a 'misrecognition and relinquishment of responsibility and accountability' (Bayer 2005:300). He does nonetheless refrain from accusing modernism of an ill-considered identification of subjectivity and self-assuredness, and from hastily accusing postmodernism of 'relativistic arbitrariness' (Bayer 2005:300). Ultimately, however, he is of the opinion that the individualistic antinomism of modernism and postmodernism will, in turn, find a canonical conclusion' (Bayer 2005:303). Additionally, '[ $t]$ he generally asserted Gospel of Freedom compels a person, due to his innate characteristic, to redeem and actualise it himself'. Thus, (post)modern man is 'condemned to freedom' (alluding to Jean-Paul Sarte, Bayer 2005:304).

By contrast, Bayer understands and posits the gospel from a Lutheran perspective, and strictly as a 'categorical gift', for which there exists 'no human disposition'. 'Gospel means: God speaks for me in the fragmentation of the time and dissipation of identities' (Bayer 2005:307). Christologically formulated this means that only 'on the strength of the incarnation of Jesus Christ my identity is reassigned to $\mathrm{me}^{\prime}$, which I have whilst existing 'within a persistent stranger'. Bayer perceives this to be in fundamental contradiction not only with 'modern metaphysics of substance but also with modern metaphysics of subject'. He thereby identifies the 'crucial point of contention in the conflict between Reformation theology and modern and postmodern thought' (Bayer 2005:308). On the other hand he considers an attitude whereby 'one receives a new - excentrical - identity', which occurs 'in faith that is founded on the authoritative Word of the Gospel' to be helpful and salutary (Bayer 2005:309).

\section{Culturally influential or critical of contemporaneity - An (apparent) alternative?}

What fundamental insights can Lutheran theology and Church provide as genuine contributions towards ecumenical Christianity, and how can these insights be communicated to our time? (Track 2004:234-275). Appertaining to this, absolutely and unconditionally, is the theme of (Christian) freedom, as put back on the agenda by Luther in 1520 . Spelled out in the Lutheran way it appears as response to the question about how I can exist before God, thus constituting the 'key question of our existence' (Beintker 1998:66-79). 
Christianity is thereby under an obligation to be critical of contemporaneity. The Church and its members can, after all, not escape contemporaneity, neither can it be denied that its members are influenced and imperceptibly governed by 'trends' and tendencies of a world and society that is not only 'all around them', but in which they live themselves and which consequently also has an effect on their being. Additionally, even in the rejection of contemporary developments where the Church or its individual members, based on their Christian responsibility, are of the opinion that they ought to be met with disapproval, and such positioning proves itself to be contemporary in nature.

For the Church to manage its contemporaneity in a critical manner, therefore, means, first and foremost, that it becomes aware of its own interwovenness with the times in which it exists. It will, therefore, first take to heart that which it voices in a critical manner to the world outside itself, if it wants to ensure the credibility of its declaration and message. Thus, the Church itself will always have to answer to the question about whether or not and to what extent the Church, together with its members, holds itself to those divine standards that it feels compelled to address. It will, thus, be obliged to confess and admit to many a transgression against divine standards, both on behalf of its members and also of itself in its aggregate. But it is exactly this stance that will not affect its credibility but rather strengthen it, provided that it is spoken, not from a position of hubris, but from one of befitting humility and informed by the knowledge of its own failings with regards to the divine standard when it speaks from its conscience in this manner. In that case a confession of guilt by the Church does have its place and is meaningful.

The insight of an unchurched contemporary has possibly been obstructed so that he, when he seeks the source of freedom, not in God but within himself - as do all those for whom God does not constitute the origin of their freedom, is condemned to actualise it in a frantic and pathological manner. However, in Man's attempt to assert his freedom he simultaneously forfeits it. Into and against this situation of what is still 'modern' man, the call of God and the Church goes out towards freedom (Bayer 1995:89-93) - but what freedom? (Brecht 1995:121-151).

\section{An ecclesiastical 'canonical' Luther}

In this context it should be noted (Klän 2011:113-117) that, where the authors of the Lutheran Confessions are concerned, Luther is regarded as being the authoritative, hermeneutic frame of reference for the proper understanding of especially the Confessio Augustana (Kolb \& Wengert 2000:601). They explicitly follow this Luther in determining the relation between the Word of God in the Holy Scriptures and the subordinate Confessions of the early Church as well as the Lutheran Reformation, so that Holy Scripture alone is the 'one true guiding principle, according to which all teachers and teaching are to be judged and evaluated' (Kolb \& Wengert 2000:527). Holy Scripture is and remains exclusively canon, whereas the Confessions take up a witness function (Kolb \&
Wengert 2000:529), admittedly with the claim to truth (Kolb \& Wengert 2000:529). By contrast, the theologians of one's own camp are at least on principle not denied the capability to err (Kolb \& Wengert 2000:529-531). During the second half of the 16th century and with this 'canonisation' of Luther, Melanchthon's scholars, who understood themselves to be Luther's heirs, have attempted to reconstitute and safeguard the tension-filled unity and polar harmony of Lutheran theology and church.

For the Lutheran Church, it is that Luther who became instrumental, with his Catechisms, in presenting the Christian community with an introduction to a life guided by God (Klän 2005:18-35). He thereby points out that Holy Baptism is God's salutary self-communication, which brings to us 'God's grace, the entire Christ, and the Holy Ghost with his gifts' (Kolb \& Wengert 2000:461). Just as the Sacrament of the Altar, which he views as 'this great a treasure, which is daily administered and distributed amongst Christians', provides the new human being with constant fortification in his battle against Satan, death and $\sin$ (Kolb \& Wengert 2000:470f.). Just as the Lord's Prayer invokes God's irrefutable willingness for mercy in just such a battle, a battle that becomes inevitable for a Christian precisely by partaking in God's self-giving and self-revelation, a Christian who, in the battle of the gospel for the gospel, takes on his enemies (Kolb \& Wengert 2000:448f., 451). Luther is perceived and presumed as being the one who construes the Credo for us, thereby gratefully accepting 'what God does for us and gives to us' (Kolb \& Wengert 2000:440) and the implementation thereof in the reality of Christ's liberation act, as Christ 'has brought us from the devil to God, from death to life, from sin to righteousness, and keeps us there' (Kolb \& Wengert 2000:434). It is that Luther who substantiates the identity of Christianity and Church as being Trinitarian, and who identifies the Christocentric aspect as being a distinctive feature of Christendom and Christianity, compared to all other forms of religiosity (and a-religiosity) that are not based on Christ or inspired by the Holy Spirit (Kolb \& Wengert 2000:440). It is the Luther who is able to discern Law and Gospel as being God's immanent manner of speaking and acting ${ }^{16}$ in which the gradient from the 'extrinsic' to the 'actual' work of God proceeds in such a way (Kolb \& Wengert 2000:585f.) that the Church must never be found wanting in proclaiming the declaration of forgiveness and the salvation in Christ, seeing that it is a matter of 'comforting and consoling' those who are frightened and 'fainthearted' (Kolb \& Wengert 2000:584).

It is precisely this Luther who delineates God's Commandments in the context of faith as a directive for everyone to make them 'a matter of daily practice in all circumstances, in all activities and dealings' (Kolb \& Wengert 2000:431) and to serve as an instruction manual for a Christian life of human sympathy that is pleasing to God. It is this Luther who places the Gospel in its forms of implementation - proclamation, baptism, Eucharist and confessional penitence as the 'third sacrament' (Kolb \& 16.Cf. the citations from Luther, Luther's exegesis of Luke $5,1-11$ in the summer homily of 1544 (Kolb \& Wengert 2000:583f.). 
Wengert 2000:465) - at the centre of an encompassing Christian understanding of a worship service (Kolb \& Wengert 2000:319). It is the Luther for whom the wording, of the sacrament's words of institution, in their literal sense, was so immovably fixed that he could not back down in this regard whenever the real presence of the body and blood of Christ in the celebratory worship of precisely this testament of Christ was called into question (Kolb \& Wengert 2000:467f.). This is, therefore, being invoked against the crypto-philippistic deviances of the second-generation theologians in Wittenberg (Kolb \& Wengert 2000:623f.). It is the Luther who, with his Christological deliberations on the conceptual conceivability of the universal presence of the human nature in Christ (even after Easter and Ascension, as well as on the promised sacramental presence of Christ sacrificed) has played a crucial role in the formation of the Lutheran profile concerning Eucharistic doctrine and Christology during the internal reformatory disputes of the 16th century. ${ }^{17}$ It is the Luther who (by the differentiation of the two realms (Kolb \& Wengert 2000:407f.), the release of secularism from clerical paternalism, as well as the theological facilitation of the differentiation between 'penultimate' and 'ultimate' [D. Bonhoeffer]) thereby paves the way for the separation of church and state (even if the Reformation churches in the Reich existed as state churches for centuries); yet without ever having relinquished God's reign of power over all ages, nations, people and spheres of life (Kolb \& Wengert 2000:389, 451). It is the Luther who urged the Christian community of solidarity to bear in mind that we 'must all indeed help us to believe, to love, to pray, and to fight against the devil' (Kolb \& Wengert 2000:476), meaning the elementary and fundamental day-to-day life of a Christian existence, advising us to engage in the lifelong practice of being a Christian.

Would it not be prudent to place the emphasis - also ecumenically - in such a way that the various Churches try to call people back into the fellowship that God grants with Himself and, in doing so, into the freedom that God bestows on those that believe? In this sense the biblicalreformatory Doctrine of Justification is at the same time 'the doctrine of Christian freedom' and as such the 'chief article of the Gospel', the preservation of which is paramount. ${ }^{18}$ In the context of the reality and effectiveness of the Gospel, the believers subsequently live in a liberated selfcircumscribed environment, albeit by means of the Will of God, the 'law' ${ }^{19}$ In this sense human freedom in the context of Christian faith and, thus, Church proclamation means: response (Bayer 1995:74), grateful response of the human being who has been liberated towards freedom by God Himself through the sacrificial, death-defying commitment of His Son (Gal 5:1). The call to return to God, the call to

17.cf. the citations from Luther, Large Confession concerning the Holy Supper (1528) (Kolb \& Wengert 2000:609f.)

18.'For it is necessary to retain the teaching of Christian freedom in the churches .... It is necessary to retain the chief article of the Gospel/Necesse est enim in ecclesiis retineri doctrinam de libertate christiana .... Necesse est retineri praecipuum evangelii locum' (AC XXVIII 51f., Kolb \& Wengert 2000:99).

19.In this context Peters ([1981] 1994:54) speaks of the 'breathing space of Christ's everlasting grace'. responsibility before God that it is the duty of a Christian to convey is indeed nothing but the call to freedom, the freedom of the children of God.

\section{Acknowledgements Competing interests}

The author declares that he has no financial or personal relationships which may have inappropriately influenced him in writing this article.

\section{References}

Aland, K., 1973, Martin Luther in der modernen Literatur, Eckart, Witten.

Assel, H., 1994, Der andere Aufbruch. Die Lutherrenaissance, Vandenhoeck \& Ruprecht, Göttingen.

Augustijn, C., 1984, 'Das marxistische Lutherbild 1983', in F. van Ingen \& G. Labroisse (eds.), Luther-Bilder im 20. Jahrhundert, Amsterdamer Beiträge zur neueren Germanistik, vol. 19, pp. 223-238, Rodopi, Amsterdam.

Balserak, J., 2013, 'Science in early modern Calvinist countries. Considering one of the sources for its flourishing', in Reformationsgeschichtliche Sozietät der MartinLuther-Universität Halle-Wittenberg (Hrsg.), Spurenlese: Kulturelle Wirkungen der Reformation, (LStRLO 20), pp. 91-103, EvangelischeVerlagsanstalt, Leipzig.

Barnbrock, C., 2003, Die Predigten C.F.W. Walthers im Kontext deutscher Auswanderer Gemeinden in den USA. Hintergründe - Analysen - Perspektiven, Kovač, Hamburg. Bayer, O., 1995, Freiheit als Antwort. Zur theologischen Ethik, Mohr Siebeck, Tübingen.

Bayer, O., 2004, Martin Luthers Theologie. Eine Vergegenwärtigung, Mohr Siebeck, Tübingen.

Bayer, O., 2005, 'Mit Luther in der Gegenwart. Die diagnostische Kraft reformatorischer Theologie', in N. Slenczka \& W. Sparn (Hrsg.), Luthers Erben. Studien zur Rezeptionsgeschichte der reformatorischen Theologie. Festschrift Jörg Baur, pp. 297-310, Mohr Siebeck, Tübingen.

Beintker, M., 1998, 'Freiheit aus Glauben - Freiheitssuche des Menschen von heute. Gemeinsamkeiten und Konflikte', in M. Beintker (Hrsg.), Rechtfertigung in der neuzeitlichen Lebenswelt. Theologische Erkundungen, pp. 66-79, Mohr Siebeck, Tübingen.

Besier, G., 2013, 'Human images, myth creation and projections: From the Luther Myth to the Luther Campaign', Kirchliche Zeitgeschichte/Contemporary Church History 26, 422-436. http://dx.doi.org/10.13109/kize.2013.26.2.422

Brecht, M., 1993, 'Philipp Jakob Spener, sein Programm und dessen Auswirkungen', in J. van den Berg \& M. Brecht (Hrsg.), Der Pietismus vom siebzehnten bis zum frühen achtzehnten Jahrhundert, vol. 1, pp. 281-389, Vandenhoeck und Ruprecht, Göttingen.

Brecht, M., 1995, 'Die Rezeption von Luthers Freiheitsverständnis in der frühen Neuzeit', Luther-Jahrbuch 62, 121-151.

Buss, H., 2013, 'Der Deutsche Luthertag 1933 und die Deutschen Christen', Kirchliche Zeitgeschichte/Contemporary Church History 26, 272-288.

Bußmann, K. \& Schilling, H., 1998, 1648 - Krieg und Frieden in Europa, Katalogband und zwei Textbände (Dokumentation der Europaratsausstellung zum 350-jährigen Jubiläum des Westfälischen Friedens in Münster und Osnabrück), Oldenbourg, Münster/Osnabrück.

Cordes, H., 2013, 'Cyprian als Chronist des Reformationsjubiläums von 1717', in K. Tanner (Hrsg.), Konstruktion von Geschichte, Jubelrede-Predigt-protestantische Historiograhie (LStRLO 18), pp. 89-103, Evangelische Verlagsanstalt, Leipzig.

Drese, C., 2013, 'Zur Geschichtsschreibung im kirchlichen Pietismus', in K. Tanner (Hrsg.), Konstruktion von Geschichte, Jubelrede - Predigt - protestantische Historiograhie (LStRLO 18), pp. 105-116, Evangelische Verlagsanstalt, Leipzig.

Dickmann, F., 1997, Der Westfälische Frieden, . 7. Auflage, Aschendorff Verlag, Münster (1998).

Elert, W., [1932] 1965a, Morphologie des Luthertums. Theologie und Weltanschauung des Luthertums hauptsächlich im 16. und 17. Jahrhundert, Beck, München.

Elert, W., [1932] 1965b, Morphologie des Luthertums. Theologie und Weltanschauung des Luthertums hauptsächlich im 16. und 17. Jahrhundert, Vol. 2: Soziallehren u. Sozialwirkungen des Luthertums, Beck, München.

Ericksen, R.P., 2013, 'The Luther anniversary and the year 1933 in the mirror of U.S Church press reports', Kirchliche Zeitgeschichte/Contemporary Church History 26 , 319-334.

Evangelische Kirche in Deutschland (EKD), 2014, Rechtfertigung und Freiheit, 500 Jahre Reformation 2017, Ein Grundlagentext des Rates der Evangelischen Kirche in Deutschland (EKD), Gütersloher Verlagshaus, Gütersloh.

Fees, K., 2014, 'Protestantische Wertekonzepte in Bildung und Wissenschaft', in Reformationsgeschichtliche Sozietät der Martin-Luther-Universität Halle-Wittenberg (Hrsg.), Spurenlese: Wirkungen der Reformation auf Wissenschaft und Bildung, Universität und Schule, Leucorea-Studien zur Geschichte der Reformation und der Lutherischen Orthodoxie 22, pp. 307-329, Evangelische Verlagsanstalt, Leipzig.

Fleischer, D., 2013, 'Protestantische Kirchengeschichtsschreibung in der Aufklärung', in K. Tanner (Hrsg.), Konstruktion von Geschichte, Jubelrede - Predigt - protestantische Historiograhie (LStRLO 18), pp. 117-139, Evangelische Verlagsanstalt, Leipzig. 
Flügel, W., 2012a, 'Konkurrenz um Reformation und Luther. Die Konfessionsjubiläen der Kirchen und der SED in den Jahren 1967 und 1983', in K. Tanner \& J. Ulrich (Hrsg.), Spurenlese, Reformationsvergegenwärtigung als Standortbestimmung (1717-1983) (LStRLO 17), pp. 239-285, Evangelische Verlagsanstalt, Leipzig.

Flügel, W., 2012b, 'Deutsche Lutheraner? Amerikanische Protestanten? Die Selbstdarstellung deutscher Einwanderer im Reformationsjubiläum 1817', in K. Tanner \& J. Ulrich (Hrsg.), Spurenlese, Reformationsvergegenwärtigung als Standortbestimmung (1717-1983) (LStRLO 17), pp. 71-99, Evangelische als Standortbestimming

Flügel, W., 2013, 'Das Beste aus zwei Welten. Geschichtskonstrukte lutherischer Pastoren im Pennsylvania des 18. Jahrhunderts', in K. Tanner (Hrsg.), Konstruktion von Geschichte, Jubelrede - Predigt - protestantische Historiograhie (LStRLO 18) pp. 179-211, Evangelische Verlagsanstalt, Leipzig.

Forster, W.O., 1953, Zion on the Mississippi. The settlement of the Saxon Lutherans in Missouri 1839-1841, Concordia, St. Louis, MO.

Frijhoff, W., 2014, 'A watchful symbiosis. Protestantisms, scholarship and higher education as (inter)national assets of the Dutch Republic', in Reformationsgeschichtliche Sozietät der Martin-Luther-Universität HalleWittenberg (Hrsg.), Spurenlese: Wirkungen der Reformation auf Wissenschaft und Bildung, Universität und Schule (LStRLO 22), pp. 107-129, Evangelische Verlagsanstalt, Leipzig.

Gäbler, U., 1984, 'Drei Typen theologischer Lutherdeutung um 1920: Ernst Troeltsch, Reinhold Seeberg, Karl Holl', in F. van Ingen \& G. Labroisse (Hrsg.), Luther-Bilder im 20. Jahrhundert, (= Amsterdamer Beiträge zur neueren Germanistik, vol. 19), pp. 187-197, Rodopi, Amsterdam.

Goeckel, R.F., 2013, 'Political an institutional issues of Lutheran churches in Communis systems. The legacy of Luther with particular reference to the GDR Churches', in Reformationsgeschichtliche Sozietät der Martin-Luther-Universität HalleWittenberg (eds.), Spurenlese: Kulturelle Wirkungen der Reformation, LeucoreaStudien zur Geschichte der Reformation und der Lutherischen Orthodoxie 20, pp. 429-445, Evangelische Verlagsanstalt, Leipzig.

Grell, O.P., 2014, 'The significance of the reformation for natural philosophy, medicine, and astronomy', in Reformationsgeschichtliche Sozietät der Martin-LutherUniversität Halle-Wittenberg (eds.), Spurenlese: Wirkungen der Reformation auf Wissenschaft und Bildung, Universität und Schule, Leucorea-Studien zur Geschichte der Reformation und der Lutherischen Orthodoxie 22, pp. 193-208, Evangelische Verlagsanstalt, Leipzig.

Heckel, M., 1983, Deutschland im konfessionellen Zeitalter (Deutsche Geschichte 5), Vandenhoeck \& Ruprecht, Göttingen.

Hennings, R., 2013, 'Die Reformationsjubiläen 1817 und 1917 in Oldenburg (Oldb.)', Kirchliche Zeitgeschichte/Contemporary Church History 26, 217-237.

Hensing, D., 1984, 'Der Bilder eigner Geist. Das schwierige Verhältnis der Lutherbilder zu ihrem Gegenstand', in F. van Ingen \& G. Labroisse (Hrsg.), Luther-Bilder im 20. Jahrhundert, (= Amsterdamer Beiträge zur neueren Germanistik, vol. 19), pp. $1-25$, Rodopi, Amsterdam.

Henze, B., 2013, 'Ohne das Konzil undenkbar. Das Reformationsgedenken 1967 in den katholischen Bistumszeitungen', Kirchliche Zeitgeschichte/Contemporary Church History 26, 347-372.

Hoenen, R., 2003, 'Günther Dehn (1882-1970) - Außenseiter für Frieden', in A. Sames (Hrsg.), 500 Jahre Theologie in Wittenberg und Halle 1502-2002. Beiträge aus der Theologischen Fakultät der Martin-Luther-Universität Halle-Wittenberg zum der Theologischen Fakultat der Martin-Luther-Universität Halle-Wittenberg zum der Lutherischen Orthodoxie 6, pp. 161-180, Evangelische Verlagsanstalt, Leipzig.

Huber, W., 2008, 'Festrede zur Eröffnung der Lutherdekade in der Schlosskirche zu Wittenberg', viewed 21 September 2008, from https://www.ekd.de/vortraege/ huber/080921_huber_wittenberg.html

Hund, J., 2013, 'Das Augustana-Jubiläum von 1830 als Kulminationspunkt der Ausbildung moderner theologischer Positionen während der Vormärzzeit', in K. Tanner (Hrsg.), Konstruktion von Geschichte, Jubelrede - Predigt protestantische Historiograhie, Leucorea-Studien zur Geschichte der Reformation und der Lutherischen Orthodoxie 18, pp. 105-116, 237-253, Evangelische und der Lutherischen

Ibsch, E., 1984, 'Nietzsches Luther-Bild', in F. van Ingen \& G. Labroisse (Hrsg.), LutherBilder im 20. Jahrhundert, (= Amsterdamer Beiträge zur neueren Germanistik, Vol. 19), pp. 79-90, Rodopi, Amsterdam.

Jarlert, A., 2013, 'Politische Inszenierung und Instrumentalisierung von Hundertjahrfeier zur Reformation im 20. Jahrhundert in Schweden', Kirchliche Zeitgeschichte/Contemporary Church History 26, 262-271.

Jasper, G., 2013, 'Vom christlichen Obrigkeitsstaat zur säkularen Demokratie. Von den Schwierigkeiten der deutschen Lutheraner im 20. Jahrhundert, die Politik zu verstehen', in Reformationsgeschichtliche Sozietät der Martin-Luther-Universität Halle-Wittenberg (Hrsg.), Spurenlese: Kulturelle Wirkungen der Reformation, Leucorea-Studien zur Geschichte der Reformation und der Lutherischen Orthodoxie 20, pp. 379-396, Evangelische Verlagsanstalt, Leipzig.

Joas, H., 2013, 'Modernisierung als kulturprotestantische Metaerzählung', in Reformationsgeschichtliche Sozietät der Martin-Luther-Universität HalleWittenberg (Hrsg.), Spurenlese: Kulturelle Wirkungen der Reformation, LeucoreaStudien zur Geschichte der Reformation und der Lutherischen Orthodoxie 20, pp. 485-496, Evangelische Verlagsanstalt, Leipzig.

Kaufmann, T., 2006, Konfession und Kultur. Lutherischer Protestantismus in der 2. Hälfte des Reformationsjahrhunderts, Mohr Siebeck, Tübingen.

Klän, W., 1999, 'Von der Reichsgründung bis zu den Reformationsjubiläen 1883', in H. Edelmann \& N. Hasselmann (Hrsg.), Nation im Widerspruch. Aspekte und Perspektiven aus lutherischer Sicht heute. Eine Studie des Ökumenischen Studienausschusses der VELKD und des DNK/LWB, pp. 145-151, Gersloher, Gütersloh.

Klän, W., 2005, 'Anleitung zu einem Gott-gelenkten Leben. Die innere Systematik der Katechismen Luthers', LuThK 29, 18-35.
Klän, W., 2011, 'Was machen wir aus Luther?', in K-H. Kandler (Hrsg.), Das Bekenntnis der Kirche zu Fragen von Ehe und Kirche. Die Vorträge der lutherischen Tage 2009 und 2010 (= Lutherisch glauben 6), pp. 90-117, Freimund, Neuendettelsau.

Koch, E., 2000, Das konfessionelle Zeitalter - Katholizismus, Luthertum, Calvinismus (1563-1675) (KGE II/8), Evangelische Verlagsanstalt, Leipzig.

Kolb, R., 1999, Martin Luther as prophet, teacher and hero, Images of the Reformer, 1520-1620, Baker Books, Grand Rapids, MI.

Kolb, R., 2011, Die Konkordienformel. Eine Einführung in ihre Geschichte und Theologie Ruprecht, Göttingen. (OUH.E 8).

Kolb, R. \& Wengert, T. (eds.), 2000, The book of Concord. The confessions of the evangelical Lutheran Church, Fortress, Minneapolis, MN.

Kranich, S., 1999, 'Martin Luther als evangelischer Schutzheiliger. Die Reformationsfeiern an der Universität Halle-Wittenberg 1927-1941', Redner und Reden in: K. Tanner \& J. Ulrich (Hrsg.), Spurenlese. Reformationsvergegenwärtigung Reden in: K. Tanner \& J.Ulrich (Hrsg.), Spurenlese. Reformationsvergegenwartigung
als Standortbestimmung (1717-1983), pp. 171-193, Leipzig. (Leucorea-Studien, als Standor
Bd. 17).

Kranich, S., 2012, 'Das Dresdner Lutherjubiläum 1883', in K. Tanner (Hrsg.), Konstruktion von Geschichte, Jubelrede - Predigt - protestantische Historiograhie, Leucorea-Studien zur Geschichte der Reformation und der Lutherischen Orthodoxie Leucorea-Studien zur Geschichte der Reformation und
18, pp. 201-243, Evangelische Verlagsanstalt, Leipzig.

Krech, V., 2013, 'Wie lebt ein Kulturprotestant? Beobachtungen zu Habitusformationen eines protestantischen Milieus', in Reformationsgeschichtliche Sozietät der Martin-Luther-Universität Halle-Wittenberg (Hrsg.), Spurenlese: Kulturelle Wartin-Luther-Universität Halle-Wittenberg (Hrsg.), Spurenlese: Kulturelle und der Lutherischen Orthodoxie 20, pp. 121-132, Evangelische Verlagsanstalt, und der
Leipzig.

Lange, D., 2005, 'E'ine andere Luther-Renaissance', in N. Slenczka \& W. Sparn (Hrsg), Luthers Erben. Studien zur Rezeptionsgeschichte der reformatorischen Theologie Luthers. Festschrift für Jörg Baur zum 75. Geburtstag, pp. 245-274, Mohr Siebeck, Lühers. Fest
Tübingen.

Laube, A., 1983, 'Martin Luthers Reformation - Teil der deutschen frühbürgerlichen Revolution', in G. Henniger (Hrsg.), Martin Luther und seine Zeit, Sonderausstellung des Museums für Deutsche Geschichte / Martin Luther Ehrung 1983 der DDR, des Museums für Deutsche Geschichte / Martin
pp. 2-5, Martin-Luther-Komitee der DRR, Berlin.

Laufhütte, H., 1984, 'Martin Luther in der deutschen Literatur des 19. und 20. Jahrhunderts', in F. van Ingen \& G. Labroisse (Hrsg.), Luther-Bilder im 20. Jahrhundert, Amsterdamer Beiträge zur neueren Germanistik, vol. 19, pp. 27-57, Brill, Leiden.

Lehmann, H., 2004, 'Das marxistische Lutherbild von Engels bis Honecker', in P. Schmidt (Hrsg.), Luther zwischen den Kulturen Zeitgenossenschaft - Weltwirkung, pp. 501-514, Vandenhoeck \& Ruprecht, Göttingen.

Lehmann, H., 2012, Luthergedächtnis 1817-2017, (Refo 500, vol. 8), Vandenhoeck \& Ruprecht, Göttingen.

Lehmann, H., 2013, 'Fragen zur Halbzeit der Lutherdekade', Kirchliche Zeitgeschichte/ Contemporary Church History 26, 447-454.

Lehmann, K. \& Pannenberg, W., 1988, Lehrverurteilungen - kirchentrennend?, Vol. 1: Rechtfertigung, Sakramente und Amt im Zeitalter der Reformation und heute, Herder, Freiburg.

Lepp, C., 2013, 'Luther in "besonderer Gemeinschaft". Die Evangelische Kirche in Deutschland, der Bund der Evangelischen Kirchen in der DDR und das Lutherjubiläum 1983', KZG 26, 412-421. http://dx.doi.org/10.13109/kize.2013.26.2.447

Ligniez, A., 2012, ““[...] BEY IETZIGEN GEFÄHRLICHEN UND BETRÜBTEN ZEITEN [...]". Zeitdiagnosen in Reformationsjubiläumspredigten 1717 in Wittenberg', in K. Tanner \& J. Ulrich (Hrsg.), Spurenlese, Reformationsvergegenwärtigung als Standortbestimmung (1717-1983) (LStRLO 17), pp. 37-70, Evangelische Verlagsanstalt, Leipzig.

Ligniez, A., 2013, 'Legitimation durch Geschichte, Das erste Reformationsjubiläum 1617 in Wittenberg', in K. Tanner (Hrsg.), Konstruktion von Geschichte, Jubelrede Predigt - protestantische Historiograhie, Leucorea-Studien zur Geschichte der
Reformation und der Lutherischen Orthodoxie 18, pp. 53-66, Evangelische Reformation und der
Verlagsanstalt, Leipzig.

Ludwig, F., 2013, 'Luther - Wahrnehmungen in Afrika, Asien und Lateinamerika', in Reformationsgeschichtliche Sozietät der Martin-Luther-Universität HalleWittenberg (Hrsg.), Spurenlese: Kulturelle Wirkungen der Reformation, LeucoreaWittenberg (Hrsg.), Spurenlese: Kulturelle Wirkungen der Reformation, Leucorea-
Studien zur Geschichte der Reformation und der Lutherischen Orthodoxie 20, Studien zur Geschichte der Reformation und der
pp. 279-307, Evangelische Verlagsanstalt, Leipzig.

Mannack, E., 1984, 'Luther - ein, geistiger Ahnherr Hitlers'?', in F. van Ingen \& G. Labroisse (Hrsg.), Luther-Bilder im 20. Jahrhundert, (= Amsterdamer Beiträge G. Labroisse (Hrsg.), Luther-Bilder im 20. Jahrhundert, (= Amsterdamer
zur neueren Germanistik, vol. 19), pp. 167-185, Rodopi, Amsterdam.

Manns, P., 1980, Martin Luther, Ketzer oder Vater im Glauben?, Lutherhaus, Hannover.

Manns, P., 1985, Martin Luther: der unbekannte Reformator; ein Lebensbild. Freiburg im Breisgau/Basel/Wien.

Manns, P. \& Loose, H.N., 1982, Martin Luther, Freiburg im Breisgau, Basel, Wien and Lahr.

Manns, P. \& Meyer, H., 1983, Ökumenische Erschließung Martin Luthers. Referate und Ergebnisse einer internationalen Theologenkonsultation, Paderborn-Frankfurt/M.

Maron, G., 1982, 'Luther 1917. Beobachtungen zur Literatur des 400. Reformationsjubiläums', ZKG 93, 1-46.

Meyer, H. \& Schütte, H. (Hrsg.), 1980, Confessio Augustana. Bekenntnis des einen Glaubens. Gemeinsame Untersuchung lutherischer und katholischer Theologen, Paderborn-Frankfurt/M.

Ökumenische Information 28, 08 July 2014.

Ökumenische Information 37, 09 September 2014. 
Pesch, O.H., 2013, 'Martin Luther im katholischen Urteil. Zwischen Verteufelung und dankbarer Aneignung', in Reformationsgeschichtliche Sozietät der MartinLuther-Universität Halle-Wittenberg (Hrsg.), Spurenlese: Kulturelle Wirkungen der Reformation, Leucorea-Studien zur Geschichte der Reformation und der der Reformation, Leucorea-Studien zur Geschichte der Reformation und der
Lutherischen Orthodoxie 20, pp. 449-483, Evangelische Verlagsanstalt, Leipzig.

Peters, A., [1981] 1994, Gesetz und Evangelium (= HST 2), Gütersloher, Gütersloh.

Pilvousek, J., 2013, 'Katholische Reaktionen auf das Luthergedenken im Jahr der Machtergreifung', Kirchliche Zeitgeschichte/Contemporary Church History 26, 335-346. http://dx.doi.org/10.13109/kize.2013.26.2.447

Pöder, C.S-V., 2013, 'Die Lutherrenaissance im Kontext des Reformationsjubiläums Gericht und Rechtfertigung bei Karl Holl, 1917-1921', Kirchliche Zeitgeschichte/ Contemporary Church History 26, 191-200. http://dx.doi.org/10.13109/ kize.2013.26.2.191

Pollack, D. \& Richter, H., 2013, 'Widerstand und Ergebung. Theologische Wurzeln politischer Standortbestimmungen in den evangelischen Kirchen in der DDR', in Reformationsgeschichtliche Sozietät der Martin-Luther-Universität HalleWittenberg (Hrsg.), Spurenlese: Kulturelle Wirkungen der Reformation, LeucoreaStudien zur Geschichte der Reformation und der Lutherischen Orthodoxie 20 pp. 397-427, Evangelische Verlagsanstalt, Leipzig.

Preuß, H., 1933, Luther und Hitler. And, as covermount: Luther und die Frauen, Wrens Park, Erlangen.

Rahner, J., 2013, 'Luther, 83 und die Folgen. Eine römisch-katholische Perspektive', Kirchliche Zeitgeschichte/Contemporary Church History 26, 400-411. http:// dx.doi.org/10.13109/kize.2013.26.2.400

Reichelt, S., 2012, 'Martin Luther als evangelischer Schutzheiliger. Die Reformationsfeiern an der Universität Halle-Wittenberg 1927-1941, Teil 1: Die Feiern', in K. Tanner \& J. Ulrich (Hrsg.), Spurenlese, Reformationsvergegenwärtigung als Standortbestimmung (1717-1983), Leucorea-Studien zur Geschichte der als Standortbestimmung (1717-1983), Leucorea-Studien zur Geschichte der
Reformation und der Lutherischen Orthodoxie 17, pp. 145-169, Evangelische Reformation und der
Verlagsanstalt, Leipzig.

Reichelt, S., 2013, 'Die Akademische Reformationsjubelfeier in Straßburg 1617', in K. Tanner (Hrsg.), Konstruktion von Geschichte, Jubelrede - Predigt - protestantische Historiograhie, Leucorea-Studien zur Geschichte der Reformation und der Lutherischen Orthodoxie 18, pp. 67-87, Evangelische Verlagsanstalt, Leipzig.

Reinhard, W., 1993, 'Historiker, "Modernisierung" und Modernisierung, Erfahrungen mit dem Konzept "Modernisierung" in der neueren Geschichte', in W. Haug \& B. Wachinger (Hrsg.), Innovation und Originalität, pp. 53-69, Walter de Gruyter, Tübingen.

Reinhard, W., 2004, Glaube und Macht. Kirche und Politik im Zeitalter der Konfessionalisierung, Herder, Freiburg.

Reinitzer, H., 2006, Gesetz und Evangelium. Über ein reformatorisches Bildthema, seine Tradition, Funktion und Wirkungsgeschichte, vol. 2, Christians, Hamburg.

Ringshausen, G., 2013, 'Das 450. Reformationsjubiläum in West und Ost', Kirchliche Zeitgeschichte/Contemporary Church History 26, 373-399. http://dx.doi. org/10.13109/kize.2013.26.2.373

Römmelt, S.W., 2013, 'Kalter Konfessions-Krieg auf Kanzel und Katheder? Die 200Jahrfeiern des Augsburger Religionsfriedens von 1755 an den Universitäten Wahrfeiern des Augsburger Religionsfriedens von 1755 an den Universitäten Wittenberg, Leipzig und Halle', in K. Tanner (Hrsg.), Konstruktion von Geschichte, Jubelrede - Predigt - protestantische Historiograhie, Leucorea-Studien zur
Geschichte der Reformation und der Lutherischen Orthodoxie 18, pp. 141-177, Geschichte der Reformation und der
Evangelische Verlagsanstalt, Leipzig. Rothe, A., 2014, 'Herausforderungen: Protestantische Bildung und
Atheismus seit 1945, Protestantische Erwachsenenbildung in der DDR', in Reformationsgeschichtliche Sozietät der Martin-Luther-Universität HalleWittenberg (Hrsg.), Spurenlese: Wirkungen der Reformation auf Wissenschaft Wittenberg (Hrsg.), Spurenlese: Wirkungen der Reformation auf Wissenschaft
und Bildung, Universität und Schule, Leucorea-Studien zur Geschichte der und Bildung, Universität und Schule, Leucorea-Studien zur Geschichte der
Reformation und der Lutherischen Orthodoxie 22, pp. 281-294, Evangelische Reformation und der
Verlagsanstalt, Leipzig.

Rublack, H.C. (Hrsg.), 1992, Die lutherische Konfessionalisierung in Deutschland. Wissenschaftliches Symposion des Vereins für Reformationsgeschichte, (SVRG 197), Gütersloher Verlagshaus, Gütersloh.

Sasse, H., [1934] 1936, Was heißt lutherisch?, Chr. Kaiser, München.

Schilling, H. (Hrsg.), 1986, Die reformierte Konfessionalisierung in Deutschland Das Problem der "Zweiten Reformation", (SVRG 195), Gütersloher Verlagshaus, Gütersloh.

Schilling, H. (Hrsg.), 1995, Katholische Konfessionalisierung, Wissenschaftliches Symposion der Gesellschaft zur Herausgabe des Corpus Catholicorum und des Vereins für Reformationsgeschichte, (SVRG 198), Gütersloher Verlagshaus, Gütersloh.

Schilling, H., 1999, Die neue Zeit, Vom Christenheitseuropa zum Europa der Staaten, 1250 bis 1750, (Siedler Geschichte Europas, vol. 3), Siedler, Berlin.

Schilling, H., 2007, Konfessionalisierung und Staatsinteressen. Internationale Beziehungen 1559-1660, = Handbuch der Geschichte der internationalen Beziehungen, hg. v. Heinz Duchhardt und Franz Knipping, Bd. 2, Paderborn Beziehungen, hg.

Schlag, T., 2014, 'Protestantische Bildungsprogramme in der Bundesrepublik Deutschland zwischen 1949 und 1990 ', in Reformationseschichtliche Sozietät der Martin-Luther-Universität Halle-Wittenberg (Hrsg.), Spurenlese: Wirkungen der Reformation auf Wissenschaft und Bildung Universität und Schule, Leucoreader Reformation auf Wissenschaft und Bildung, Universitat und Schule, LeucoreaStudien zur Geschichte der Reformation und der
pp. 255-279, Evangelische Verlagsanstalt, Leipzig.

Schluß, H., 2014, 'Die Reformation als Bildungskatastrophe - Luthers Pädagogik zwischen Mangel und Utopie', in Reformationsgeschichtliche Sozietät der Martin-Luther-Universität Halle-Wittenberg (Hrsg.), Spurenlese: Wirkungen der Reformation auf Wissenschaft und Bildung, Universität und Schule, LeucoreaStudien zur Geschichte der Reformation und der Lutherischen Orthodoxie 22, pp. 69-89, Evangelische Verlagsanstalt, Leipzig.
Schneider, N. (President) (2011). 'Am Anfang war das Wort'. Dachmarkenkampagne Luther 2017 heute in Berlin vorgestellt: 27 October 2011, viewed 24 March 2014, from http://www.ekd.de/presse/pm247_2011_dachmarkenkampagne.html

Schönstädt, H-J., 1978, Antichrist, Weltheilsgeschehen und Gottes Werkzeug, Römische Kirche, Reformation und Luther im Spiegel des Reformationsjubiläums
1617 , Veröffentlichungen des Instituts für Europäische Geschichte Mainz 80 Steiner, Wiesbaden.

Schönstädt, H-J., 1982a, 'Das Reformationsjubiläum 1617', ZKG 93, 5-57.

Schönstädt, H-J., 1982b, 'Das Reformationsjubiläum 1717', ZKG 93, 58-118.

Schorn-Schütte, L., 2013, 'Religion und Politik. Grundzüge einer christlichen Herrschaftslehre im 16. Jahrhundert', in Reformationsgeschichtliche Sozietät der Martin-Luther-Universität Halle-Wittenberg (Hrsg.), Spurenlese: Kulturelle Wirkungen der Reformation, Leucorea-Studien zur Geschichte der Reformation und der Lutherischen Orthodoxie 20, pp. 17-40, Evangelische Verlagsanstalt, Leipzig.

Schweizer, F., 2014, 'Protestantisches Bildungserbe? Fragen evangelischer Bildungsverantwortung heute, Fees, K., 2014, Protestantische Wertekonzepte in Bildung und Wissenschaft', in Reformationsgeschichtliche Sozietät der Martin-Luther-Universität Halle-Wittenberg (Hrsg.), Spurenlese: Wirkungen der Martin-Luther-Universität Halle-Wittenberg (Hrsg.), Spurenlese: Wirkungen der
Reformation auf Wissenschaft und Bildung, Universität und Schule, LeucoreaReformation auf Wissenschaft und Bildung, Universität und Schule, Leucorea-
Studien zur Geschichte der Reformation und der Lutherischen Orthodoxie 22, Studien zur Geschichte der Reformation und der
pp. 331-347, Evangelische Verlagsanstalt, Leipzig.

Siemon-Netto, U., 1993, Luther als Wegbereiter Hitlers?: zur Geschichte eines Vorurteils, Gütersloher Verlagshaus, Gütersloh.

Söding, T., 2014, '500 Jahre Reformation - der Versuch einer Rechtfertigung', Christ in der Gegenwart, 03 August, p. 31.

Sommer, W., 1988, Gottesfurcht und Fürstenherrschaft. Studien zum Obrigkeitsverständnis Johann Arndts und lutherischer Hofprediger zur Zeit der altprotestantischen Orthodoxie, Vandenhoeck \& Ruprecht, Göttingen.

Sommer, W., 1999, Politik, Theologie und Frömmigkeit im Luthertum der Frühen Neuzeit, Vandenhoeck \& Ruprecht, Göttingen.

Slenczka, N., 1999, Selbstkonstitution und Gotteserfahrung. W. Elerts Deutung der neuzeitlichen Subjektivität im Kontext der Erlanger Theologie. Studien zur Erlanger neuzeitlichen Subjektivität im Kontext der Erlanger The
Theologie II, Vandenhoeck \& Ruprecht, Göttingen.

Slenczka, N., 2004, 'Luthertum und Neuzeit. Bemerkungen zum ambivalenten Verhältnis von Rechtfertigungsglauben und neuzeitlicher Subjektivität', in R. Rittner (Hrsg.), Was heißt hier lutherisch!, Aktuelle Perspektiven aus Theologie und Kirche, pp. 164-192, Lutherhaus, Hannover.

Stengel, F., 2013, 'Die Universität und ihr Name - Martin Luther. Kontexte de Verleihung 1933', Kirchliche Zeitgeschichte/Contemporary Church History 26, 289-318. http://dx.doi.org/10.13109/kize.2013.26.2.289

Tanner, K. \& Ulrich, J. (Hrsg.), 2012, Spurenlese, Reformationsvergegenwärtigung als Standortbestimmung (1717-1983), Leucorea-Studien zur Geschichte der Reformation und der Lutherischen Orthodoxie 17, pp. 195-237, Evangelische Verlagsanstalt, Leipzig.

Tenorth, H-E., 2014, 'Konfessionalität in Bildungspolitik, Bildungssystem und pädagogischer Reflexion in beiden deutschen Staaten nach 1945 Oder: der Bedeutungsverlust einer historisch bedeutsamen Struktur', in Reformationsgeschichtliche Sozietät der Martin-Luther-Universität HalleWittenberg (Hrsg.), Spurenlese: Wirkungen der Reformation auf Wissenschaft und Bildung, Universität und Schule, Leucorea-Studien zur Geschichte der Reformation und der Lutherischen Orthodoxie 22, pp. 241-254, Evangelische Verlagsanstalt, Leipzig.

Thönissen, W., 2013, 'Katholische Perspektiven zum Thema "Reformationsjubiläum", Kirchliche Zeitgeschichte/Contemporary Church History 26(2), 437-446. http:// dx.doi.org/10.13109/kize.2013.26.2.437

Track, J., 2004, 'Die lutherische Stimme in der Ökumene', in R. Rittner (Hrsg.), Was heißt hier lutherisch!, Aktuelle Perspektiven aus Theologie und Kirche, pp. 234-275, Lutherhaus, Hannover.

Ulrichs, H-G., 2013, 'Eine “Gelegenheit, mit den unbekannten Vätern der reformierten Kirche bekannt zu machen". Das Reformationsjubiläum 1917 in Emden und bei den Reformierten in Deutschland', Kirchliche Zeitgeschichte/Contemporary den Reformierten in Deutschland', Kirchliche Zeitgeschichte/Contempora
Church History 26, 238-261. http://dx.doi.org/10.13109/kize.2013.26.2.238

Van Ingen, F., 1984, 'Die Erasmus-Luther-Konstellation bei Stefan Zweig und Thomas Mann', in F. van Ingen \& G. Labroisse (Hrsg.), Luther-Bilder im 20. Jahrhundert (= Amsterdamer Beiträge zur neueren Germanistik, vol. 19), pp. 91-118, Rodopi, Amsterdam.

Von Meding, W., 1982, 'Jubel ohne Glauben? Das Reformationsjubiläum 1817 in Württemberg', ZKG 93, 119-160.

Weber, W.E.J., 2014, 'Protestantismus, Universität und Wissenschaft, Kritische Bemerkungen zu einer historischen Aneignung', in Reformationsgeschichtliche Sozietät der Martin-Luther-Universität Halle-Wittenberg (Hrsg.), Spurenlese: Wirkungen der Reformation auf Wissenschaft und Bildung, Universität und Schule, Leucorea-Studien zur Geschichte der Reformation und der Lutherischen Orthodoxie 22, pp. 19-38, Evangelische Verlagsanstalt, Leipzig.

Wellenreuther, H., 2013, 'Zivilisation, Mission und Kirchenverständnis. Europäische protestantische und indigene Kirchen', in Nordamerika in Reformationsgeschichtliche Sozietät der Martin-Luther-Universität HalleWittenberg (Hrsg.), Spurenlese: Kulturelle Wirkungen der Reformation, LeucoreaStudien zur Geschichte der Reformation und der Lutherischen Orthodoxie 20, pp. 309-330, Evangelische Verlagsanstalt, Leipzig.

Wendebourg, D., 2011, 'Die Reformationsjubiläen des 19. Jahrhunderts', ZThK 108 270-335.

Willenberg, N., 2012, 'Mit Luther und Hitler für Glauben und Volkstum. Der Luthertag 1933 in Dresden', in K. Tanner \& J. Ulrich (Hrsg.), Spurenlese,
Reformationsvergegenwärtigung als Standortbestimmung (1717-1983), Reformationsvergegenwärtigung als Standortbestimmung (1717-1983),
Leucorea-Studien zur Geschichte der Reformation und der Lutherischen Orthodoxie Leucorea-Studien zur Geschichte der Reformation und der
17, pp. 195-237, Evangelische Verlagsanstalt, Leipzig. 
Wischmeyer, J., 2013, 'Reformation als Epoche und Strukturmoment Protestantismustheorie und Historismus bei Karl von Hase und der Jenaer freisinnigen Theologie', in K. Tanner (Hrsg.), Konstruktion von Geschichte, Jubelrede - Predigt - protestantische Historiograhie, Leucorea-Studien zur Geschichte der Reformation und der Lutherischen Orthodoxie 18, pp. 277-306, Evangelische Verlagsanstalt, Leipzig.

Wischmeyer, J., 2014, 'Leitbilder des protestantischen Theologiestudiums. Programmatische Diskussion und institutioneller Wandel vom 16. Bis ins 20. Jahrhundert', in Reformationsgeschichtliche Sozietät der Martin-LutherUniversität Halle-Wittenberg (Hrsg.), Spurenlese: Wirkungen der Reformation auf Wissenschaft und Bildung Universität und Schule, Leucorea-Studien zur Geschichte der Reformation und der Lutherischen Orthodoxie 22, pp. 59-63, Evangelische Verlagsanstalt, Leipzig.
Wolff, C., 2014, 'Musik aus dem Geist der Reformation. Bibel und Gesangbuch in der Musik Johann Sebastian Bachs', in Reformationsgeschichtliche Sozietät der MartinLuther-Universität Halle-Wittenberg (Hrsg.), Spurenlese: Kulturelle Wirkungen der Reformation, Leucorea-Studien zur Geschichte der Reformation und der Lutherischen Orthodoxie 20, pp. 350-362, Evangelische Verlagsanstalt, Leipzig.

Wolter, H., 1982, 'Das Reformationsjubiläum von 1817 in der Freien Stadt Frankfurt am Main', ZKG 93, 161-176.

Wriedt, M., 2014, 'Erleuchtete Pietas-fromme Erudition.Zum Wandel des theologischen Bildungsverständnisses im Zeitalter der Aufklärung' in Reformationsgeschichtliche Sozietät der Martin-Luther-Universität Halle-Wittenberg (Hrsg.), Spurenlese: Wirkungen der Reformation auf Wissenschaft und Bildung Universitöt und Schule, Wirkungen der Reformation auf Wissenschaft und Bildung, Universität und Schule, 22, pp. 159-191, Evangelische Verlagsanstalt, Leipzig. 